\title{
Underground Tank Vitrification: Engineering-Scale Test Results
}

B. E. Campbell

C. L. Timmerman

W. F. Bonner

June 1990

Prepared for the U.S. Department of Energy under Contract DE-AC06-76RLO 1830

Pacific Northwest Laboratory Operated for the U.S. Department of Energy by Battelle Memorial Institute

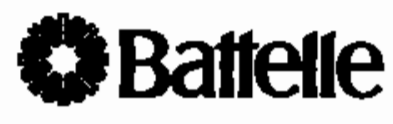




\title{
DISCLAIMER
}

This report was prepared as an account of work sponsored by an agency of the United States Government. Neither the United States Government nor any agency thereof, nor Battelle Memorial Institute, nor any of their employees, makes any warranty, expressed or implied, or assumes any legal Ilabilty or responsibulity for the accuracy, completeness, or usefulness of any information, apparatus, product, or process disclosed, or represents that its use would not infringe prtvatehy owned rights. Reference herein to any specific commercial product, process, or service by trade name, trademark, manufacturer, or otherwise, does not necessarily constitute or imply its endorsement, recommendation, or favoring by the United States Government of any agency thereof, or Battelle Memorial Institute. The views and opinions of authors expressed herein do not necessarily state or reflect those of the United States Government or any agency thereof.

\author{
PACIFIC NORTHWEST LABORATORY \\ operated by \\ BATTELLE MEMORIAL INSTITUTE \\ for the \\ UNITED STATES DEPARTMENT OF ENERGY \\ under Contract DE-ACO6-76RLO 1830
}

Printed in the United States of America

Available to DOE and DOE contractors from the

Office of Scientific and Technical Information, P.O. Box 62, Oak Ridge, TN 37831; prices available from (615) 576-8401. FTS 626-8401.

Available to the public from the National Technical Information Service, U.S. Department of Commerce, 5285 Port Royal Rd., Springfield, VA 22161.

NTIS Price Codes, Microfiche A01

Printed Copy

\begin{tabular}{cr}
\hline Price Code & Page Range \\
\hline A02 & $1-10$ \\
A03 & $11-50$ \\
A04 & $51-75$ \\
A05 & $76-100$ \\
A06 & $101-125$ \\
A07 & $126-150$ \\
A09 & $151 \cdot 175$ \\
A09 & $176-200$ \\
A10 & $201-225$ \\
A11 & $226-250$ \\
A12 & $251-275$ \\
A13 & $276-300$ \\
A14 & $301-325$
\end{tabular}

\begin{tabular}{cc}
\hline Prce Code & Page Range \\
\hline A15 & $326-350$ \\
A16 & $351-375$ \\
A17 & $376-400$ \\
A18 & $401-425$ \\
A19 & $426-450$ \\
A20 & $451-475$ \\
A21 & $476-500$ \\
A22 & $501-525$ \\
A23 & $526-550$ \\
A24 & $551-575$ \\
A25 & $576-600$ \\
A99 & $601-U p$
\end{tabular}


PNL -7295

UC -602

UNDERGROUND TANK VITRIFICATION:

ENGINEERING-SCALE TEST RESULTS

B. E. Campbe 11

C. L. Timmerman

W. F. Bonner

June 1990

Prepared for the U.S. Department of Energy under Contract DE-ACO6-76RLO 1830

Pacific Northwest Laboratory

Richland. Washington 99352 


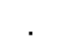

. 


\section{SUMMARY}

Contamination associated with underground tanks at U.S. Department of Energy sites and other sites may be effectively remediated by application of in situ vitrification (ISV) technology. In situ vitrification converts contaminated scil and buried wastes such as underground tanks into a glass and crystalline block, similar to obsidian with crystalline phases. A radioactive engineering-scale test performed at Pacific Northwest Laboratory in September 1989 demonstrated the feasipility of using ISV for this application. A $30-\mathrm{cm}$ diameter (12-in.-diameter) buried steel and concrete tank containing simulated tank sludge was vitrified, producing a solid block. The tank sludge used in the test simulated materials in tanks at Oak Ridge National Laboratory. Hazardous components of the tank sludge were immobilized or removed and captured in the off-gas treatment system. The steel tank was converted to ingots near the bottom of the block and the concrete walls were dissolved into the resulting glass and crystalline block. Although one of the four moving electrodes "froze" in place about halfway into the test, operations were able to continue. The test was successfully completed and all the tank sludge was vitrified. 


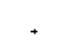

.

. 


\section{ACKNOWLEOGMENIS}

The authors wish to thank Tom Powell, senior technician at Pacific Northwest Laboratory, for his dedication and knowledge in completing this test in an accurate and timely manner. 


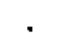

. 


\section{CONTENTS}

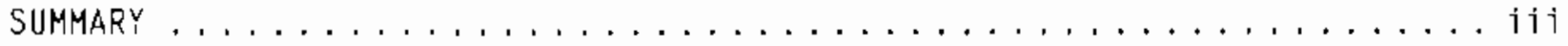

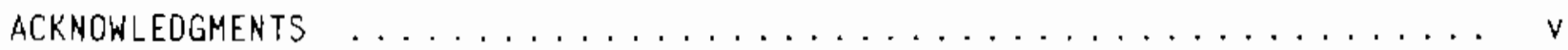

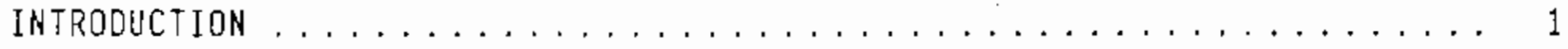

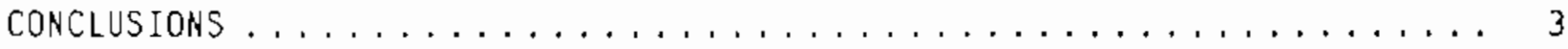

DESCRIPTION OF UNDERGROUND TANK VITRIFICATION $\ldots \ldots \ldots \ldots$

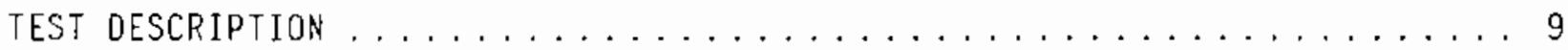

SLUOGE AND SOIL CHARACTERIZATION $\ldots \ldots \ldots \ldots \ldots \ldots \ldots$

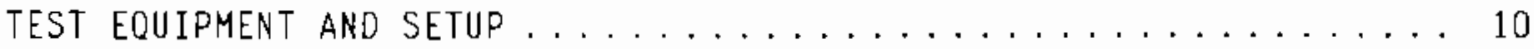

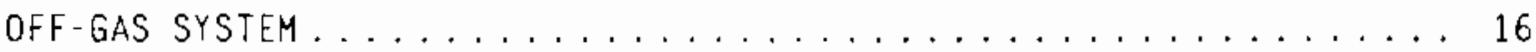

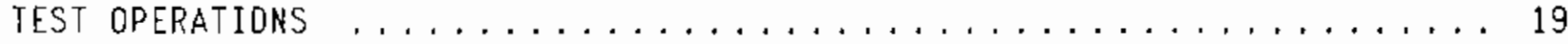

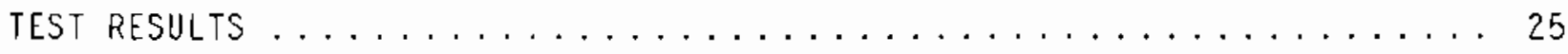

CHARACTERIZATION OF GLASS PROOUCT AND SURROUNOING SOIL $\ldots \ldots \ldots . \ldots 25$

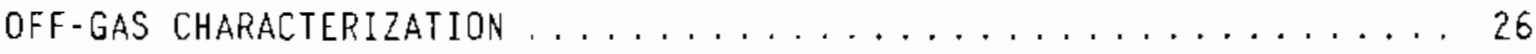

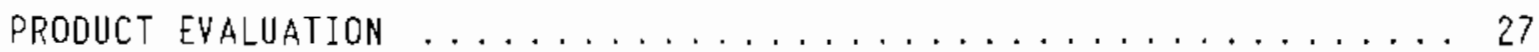

RETENTION OF RADIONUCLIDES AND haZARDOUS CHEMICALS $\ldots \ldots \ldots \ldots$

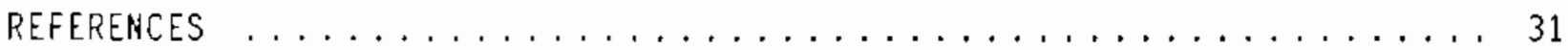




\section{EIGURES}

1. Operating Sequence for Underground Tank Vitrification ........ 5

2. Engineering-Scale Test Containment .................. 12

3. Schematic of Engineering-Scale ISV Test Configuration..........13

4. Electrode Feeding system ....................... 14

5. Metal Tank Prior to Addition of Concrete Coating ............ 15

6. Simulated Tank in vitrification Test Chamber ............. 16

7. Engineering-Scale Sampling System ................... 17

8. Electrical Power Input to UTV Test ................... 20

9. UTV Engineering-Scale Vitrified Block ................ 20

10. Glass Produced from Underground Tank Vitrification,........... 22

11. Electrode Feed Rates ......................... 22

12. Comparison of Electrode Depth to Vitrification Depth .........23

\section{IABLES}

1. Concentrations of Radionuclide and Hazardous Components

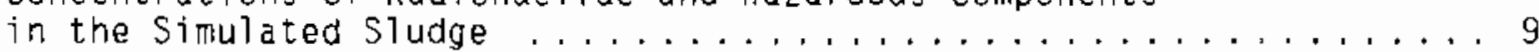

2. Composition of Uncontaminated ORNL Sort .............. 11

3. EP Toxicity Concentrations for the UTV Engineering-Scaie

Product $\ldots \ldots \ldots \ldots \ldots \ldots \ldots$

4. Contaminant Retention in the vitrified soil .............. 29

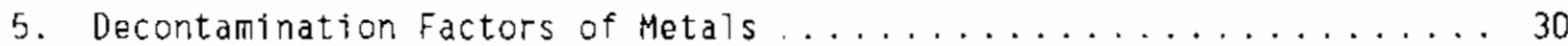




\section{INTRODUCTION}

Underground storage tanks containing sludges and salt cakes of radioactive and/or hazardous chemicals are present at many U.S. Department of Energy (DOE) sites. Recent enactment of stringent environmental regulations requires timely remediation of certain inactive tanks. Studies evaluating tank remediation alternatives show that many of the tanks can be stabilized in place. This option not only represents significantly less cost, but the risks of personnel exposure and environmental release are greatly reduced by eliminating the need to exhume and handle the contaminated materials. Tanks containing material that cannot be economically removed and tanks with outlying soil contamination are likely candidates for in-place treatment by in situ vitrification (ISW). Funded by the Hazardous Waste Remedial Action Program. this project provides a technique for cost-effectively remediating contaminated underground tanks.

In situ vitrification is a process that converts contaminated soils and sludges into a durable glass and crystalline product that is similar to obsidian commingled with crystalline phases. The system is based on the jouleheating principle of glass melter technology developed at Pacific Northwest Laboratory ( $P N L$ ) (a) for immobilizing high-level nuclear waste. In situ vitrification was originally tested by researchers at PNL in August 1980 (U.S Patent 4,376,598 - Brcuns. Buelt, and Bonner 1983). Since then, this technology has been developed through a series of bench-, engineering-, pilot-, and large-scale tests. Vitrification of contaminated soil has been evaluated in 74 separate tests under a variety of waste and soll conditions. These include 17 pilot-scale tests, each processing 10-50 metric tonnes ( $t$ ) of contaminated soil. and 5 large-scale tests. each processing 400-800 $t$ of contaminated soil. In situ vitrification has emerged in recent years as a technology that is ready for field demonstration and application for many waste types and soil conditions.

One of the most promising applications for ISV is remediation of underground storage tanks. By filling the tanks with clean or contaminated soil and vitrifying the tank, tank contents, and surrounding soil, not only are the tank contents immobilized, but soil contaminated from possible leakage outside the tank is also stabilized. Although only a conceptual analysis has been

(a)Pacific Northwest Laboratory is operated by Battelle Memorial Institute for the U.S. Department of Energy under contract DE-ACO6-76RLO 1830. 
performed for underground storage tanks, the cost of the vitrification operation itself may not be greatly more than for contaminated sojl sites. Using conservative assumptions, the estimated tank vitrification costs represent the possibility of more than an order-of-magnitude savings in costs over present orojections for cleanup of tanks containing mixed waste. Consequently. ISV capabilities are being demonstrated on underground tanks to provide a useful tool to DOE for remediation actions.

The Underground Tank Vitrification (UTV) project is underway at PNL to assess the application of ISV in remediating unoerground storage tanks. Since most DOE sites contain contaminated underground storage tanks, personnel from each of the major DOE sites were contacted for information regarding the characteristics of tanks at each site. Based upon site needs, this project is proceeding in two phases: 1) vitrification of tanks up to $8 \mathrm{~m}(20 \mathrm{ft})$ in diameter containing sludges, and 2) vitrification cf large tanks containing mainly salts. An engineering-scale test was performed as part of phase 1 testing based on data cotained from 33 recently sameled tanks at 0ak Ridge National Laboratory (ORNL)(Autrey et al. 1989). A scaled tank containing a hazardous and radioactive simulated sludge was used for this engineering-scale test. The primary purpose of the test was to determine the applicability of ISW in treating underground tanks containing residual radioactive and hazardous sludges, and to study the immobilization of an underground tank, connecting piping, tank contents, and surrounding soil, Other objectives for the test are listed below:

- demonstrate ISV operations on an undergrourid tank

- evaluate hazardous material retention, immobilization, destruction, volatilization. and thermal transport effects

- assess the use of electrode feeding on an underground tank

- evaluate tank pressure effects during ISV operations.

This report oresents the results of the engineering-scale ISV treatability test conducted on a simulated underground storage tank containing a simulated residual sludge. The report provides conclusions based on test results, a brief description of the ISV technology and how it operates, a description of the specific engineering-scale treatability test, and a summary and analysis of the test results. 


\section{CONCLUSIONS}

A radioactive engineering-scale test conducted by PNL in September 1989 has demonstrated the feasibility of using ISW to remediate contaminated underground storage tanks at DOE sites. In this test. a $30-\mathrm{cm}^{-2}$ diameter stee? and concrete tank was converted to a solid vitrified block. The tank. which contained simulated tank sludge and soil. Was buried $15 \mathrm{~cm}(6 \mathrm{in}$.) below surface. The contents of the tank were representative of material within the buried tanks and surrounding soil at ORNL. Conclusions based on the test results are listed below:

- Metal and/or concrete tanks can be vitrified by filling the tank with soil and applying ISW.

- The electrode feeding system used for this application is adequate for UTV. Electrical shorting through a continuous metallic layer is prevented sy raising one or more of the electrodes in the event of electrical shorting. In addition, use of coated graphite electrodes, rather than the more expensive and complex molybdenum/graphite composite electrodes. is feasible.

- Sludge components are destroyed during processing and/or immobilized in the ISV block. Volatile species are collected in the offgas treatment system. High retention (>99.9\%) was demonstrated for nonvolatile metals ( $\mathrm{Cr}, \mathrm{U}, \mathrm{CS}, \mathrm{Sr}$, and $\mathrm{TC}$ ). Lower retention (15-50\%) was shown for $\mathrm{Pb}$ and $\mathrm{Hg}$; however, volat llized species are collected in the off-gas treatment system by scrubbing and filtration.

- The vitrified product shows a homogeneous distribution of hazardous constituents.

- No detectable transport of hazardous constituents to surrounding soil was observed.

- Samples of the ISV-generated glass and metal phases subjected to Extraction Procedure Toxicity (EP Tox) testing each produced leach concentrations significant1y below the U.S. Environmental

Protection Agency (EPA) Timits. 
$-$ 


\section{DESCRIPLION OF UNDERGROUND TANK VITRIEICALION}

The UTV process converts underground tanks and associated hazardous materials to a solid block. thereby immobilizing the contaminated tank. sludge, and surrounding soil. Figure 1 depicts the UTV process. Prior to treatment by ISV. contaminated underground tanks are filled with soil and all attendant piping is blocked off. A hood for containment of volatilized materials and support of the electrodes is placed over the area to be vitrified. A square array of four silicon carbide-coated graphite electrodes is inserted a few centimeters into the ground. Because soil is not electricaliy conductive when moisture has been driven off, a graphite and glass frit starter material is spread between the electrodes to form a conductive starter path. An electric potential applied to the electrodes establishes an electric current in the starter path. The resultant power heats the starter path. creating temperatures high enough to melt the soil (typically about $1700^{\circ} \mathrm{C}$ ). The starter path is consumed by oxidation. and the current is transferred to the molten soil. which is electrically conductive.

As the molten zone grows downward. the electrodes are allowed to move at the same rate. As the molten soil encounters a metal object such as a steel tank, the nigh temperatures melt the metal and the metal flows to the bottom of the molten pool. Other materials encountered, such as concrete. decompose and dissolve in the molten mass. The enlarging molten mass encompasses the soil. tank wall, and sludge in the bottom of the tank. Melting may also

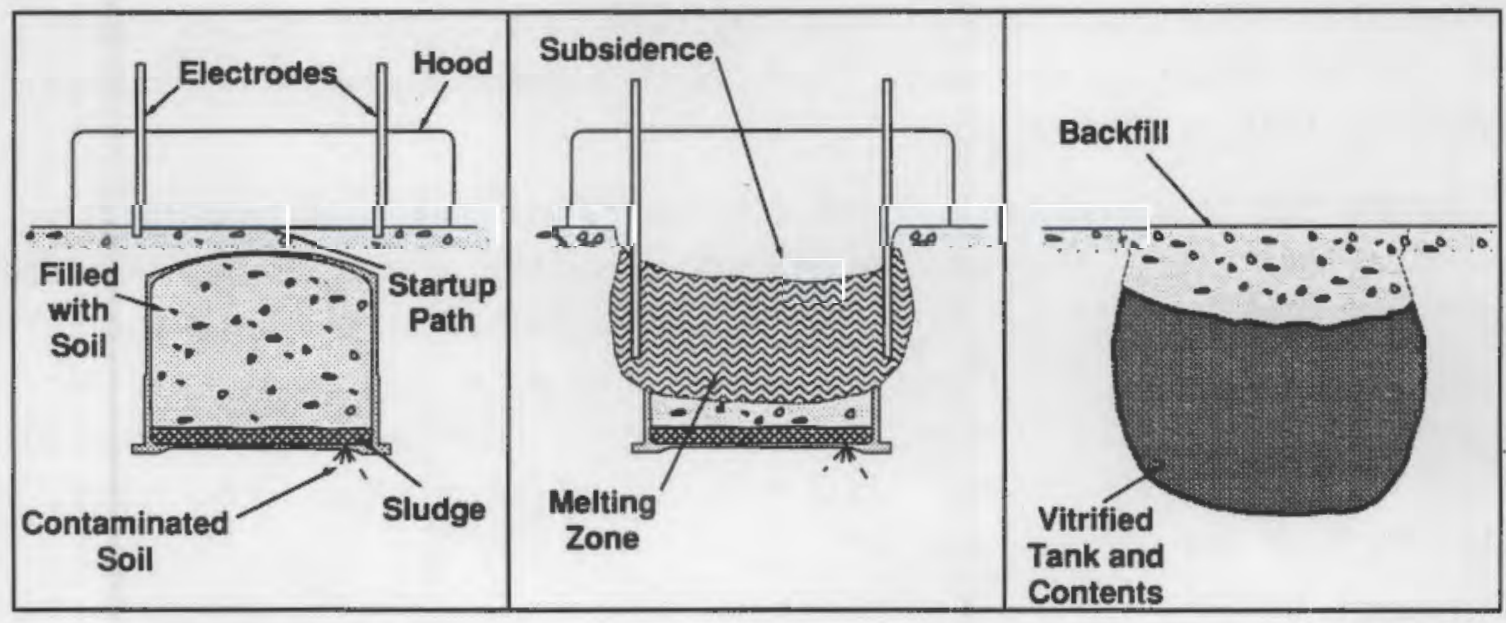

38910101.1

EIGURE 1. Operating Sequence for Underground Tank Vitrification 
continue downward. if desired, to immobilize contaminated soll below the tank. The melt incorporates radionuclides and nonvolatile hazardous elements such as heavy metals, and destroys organic components by pyrolysis. The pyrolyzed byproducts migrate to the surface of the vitrified zone, where they burn in the presence of air. The metal tank melts and forms ingots near the bottom of the melted mass.

As the vitrified zone grows, the resistance of the melt decreases, thus requiring periodic adjustments of the ratio between the voltage and the current to maintain operation at a constant power. Operations for each pair of electrodes follow the power equation

$$
P=I^{2} \times R
$$

where $P=$ power, $I=$ current, and $R=$ resistance. The PNL large-scale ISV system primarily consists of five major subsystems: 1) electrical power supply. 2) off-gas hood, 3) off-gas treatment, and 4) process control.

The PNL large-scale system contains a $3750-\mathrm{kW}$ power system. Operating typically at an energy-to-mass ratio of $0.8 \mathrm{~kW} / \mathrm{kg}$ of product, the process is capable of melting soil at 3 to $5 \mathrm{t} / \mathrm{h}$.

The product resulting from ISV is a glass and crystalline mass resembling natural obsidian and a metal ingot. For typical earthen materials, final ISV block density varies from 2.3 to $2.5 \mathrm{~g} / \mathrm{cm}^{3}\left(144-156 \mathrm{lb} / \mathrm{ft}^{3}\right)$. Though the ISV block is only $3 \%$ to $11 \%$ heavier than concrete, it possesses about 5 to 10 times the strength of unreinforced concrete in both tension and compres sion. The ISV block is extremely inert, with a chemical leach resistance approaching that of Pyrex@glass.

Except for the hood, all of the ISY components are contained in three transportable trailers that can be moved to any site over a compacted surface. The off-gas hood and off-gas line. which are installed at the site for collecting gaseous effluents, are dismantled and placed on a flatbed trailer for transport between tanks. The effluents exhausted from the hood are cooled and treated in the off-gas treatment system. The entire process is monitored and controlled from the process trailer.

(a) Pyrex is a registered tradename of E.I. duPont de Nemours and Company, Wilmington, Delaware. 
The off-gas treatment system is the most complex and expensive of the components. It cools, scrubs, and filters the gaseous effluents exhausted from the hood. Its primary components include a wet-scrubber system, two heat exchangers, two process scrub tanks, two scrub solution pumps, mist eliminators. a heater, a charcoal/filter assembiy, and a blower system.

For routine operations on a site, all three trailers are coupled and may be moved from one tank to another by pulling them as a unit. The off-gas hood, electrode feed system, and off-gaslines are moved by crane for use on nearby tanks or dismantled and placed on a flatbed trailer for transport between distant tanks. 



\section{IEST DESCRIPIION}

This section describes the pre-test soil characterization, the engineering-scale test equipment and setup, and the off-gas system used for the test. The test was conducted using the engineering-scale test equipment located in the Engineering Development Laboratory 101 of the 324 Building at Hanford.

\section{SLUDGE AND SOIL CHARACTERIZALION}

This section outlines the compositions of the chemically simulated sludge and the uncontaminated ORNL soil used as tank flller and surrounding material. Of interest in this test was the ability of the ISV process to treat tanks with residual sludges containing radionuclides and hazardous materials. To maximize the applicability of the data produced from this test. analyses of the contents of inactive ORNL tanks were reviewed (Autrey et al. 1989). Typical maximum concentrations of hazardous and radioactive species were identified. These concentrations were compared with projected minimum detectable concentrations in the ISV block, soil, and off gas, and the highest value was selected. The objective was to select the sludge composition that would present the most challenge to ISV. Table 1 lists the components and

IABLE 1. Concentrations of Radionuclide and Hazardous Components in the Simulated Siudge

\begin{tabular}{lc} 
Component & Concentration. wt\% \\
\cline { 1 - 2 } $0 \mathrm{il}$ & 1.0 \\
$\mathrm{Cr}_{2} \mathrm{O}_{3}$ & 0.04 \\
$\mathrm{HgO}$ & 0.005 \\
$\mathrm{~Pb}$ & 0.005 \\
$\mathrm{UO}_{3}$ & 0.9 \\
$\mathrm{CsNO}_{3}$ & 0.4 \\
$\mathrm{SrCO}_{3}$ & 4.6 \\
$\mathrm{CoO}$ & 0.35 \\
$\mathrm{TC}-99$ & 0.003 \\
$\mathrm{H}_{2} \mathrm{O}$ & 12.9 \\
Soil & 79.8 \\
Total & 100.0
\end{tabular}


their concentrations in the simulated sludge. Radioactive species used in this test were depleted uranium and technetium. Hazardous species such as chromium, mercury, and lead were typically found to be present in the waste sludges and were therefore used in the simulant. Although the ORNL test results did not indicate the presence of technetium, it is expected to be pre. sent in the sludge. Performance analyses performed by PNL (Sewart et a). 1987) in support of the Hanford Grout Facility show that long-term dose to maximally exposed individuals is a strong function of the technetium concentration in the waste. Therefore, knowledge of technetium behavior during ISv is important. A light machine oil was used in the test to simulate a mixture of organic materials found in several of the tanks.

Pre-test sampling of the uncontaminated ORNL soil was performed to identify the presence of any hazardous sludge components. No significant concentrations of contaminants were found. This sampling also determined the presence and quantity of glass-forming materials (1.e., $\mathrm{SiO}_{2}$ and $\mathrm{Al}_{2} \mathrm{O}_{3}$ ) and fluxes (i.e.. $\mathrm{Na}_{2} \mathrm{O}, \mathrm{K}_{2} \mathrm{O}$ and $\mathrm{CaO}$ ) that would contribute to proper melting at the ISV process temperature range of $1200^{\circ} \mathrm{C}$ to $2000^{\circ} \mathrm{C}$ (Table 2).

\section{IEST EOUIPMENT AND SETUP}

The PNL engineering-scale unit consists of a 1.8-m- (6-ft-) diameter by 2.4-m- (8-ft-) tall sealed chamber containing the tank and soil to be vitrified (Figure 2). Four graphite cylindrical electrodes are placed $30 \mathrm{~cm}$ (12 in.) apart in a square array and fed vertically into the soil that surrounds the tank. Figure 3 diagrams the setup for the engineering-scale test. For this test, uncontaminated ORNL soil was used to surround the tank and fill the void space within the tank. The containment module is capable of operation at a slightly negative pressure to contain and sample off gases generated during the process. The off gases from the vitrified area can be continuously sampled throughout the test. The test was conducted using four $5.1-\mathrm{cm}$ (2.0-in.-) diameter, silicon carbide-coated graphite electrodes (Figure 2). The electrodes were coated to prevent excessive oxidation that could otherwise occur at the interface of the oxygen-containing hood environment and the molten soil. The electrode feed system is shown in Figure 4. Gravity feeding was used in this test, as opposed to buried, fixed electrodes, to allow recovery from shorting conditions that could occur due to the metal contained within the test zone. A shorting condition occurs when a continuous molten 
IABLE 2. Composition of Uncontaminated ORNL Soil

\begin{tabular}{|c|c|c|}
\hline & Uncontam & d Soil \\
\hline Component & $\begin{array}{l}\text { Total } \\
\text { Soil. } \\
\text { wt\% } \\
\end{array}$ & $\begin{array}{c}\text { Dry } \\
\text { Basis, } \\
\text { wt\% } \\
\end{array}$ \\
\hline $\mathrm{Al}_{2} \mathrm{O}_{3}$ & 16.1 & 18.7 \\
\hline $\mathrm{B}_{2} \mathrm{O}_{3}$ & 0.04 & 0.05 \\
\hline $\mathrm{BaO}$ & 0.05 & 0.06 \\
\hline $\mathrm{CaO}$ & 9.28 & 10.8 \\
\hline $\mathrm{Cr}_{2} \mathrm{O}_{3}$ & 0.02 & 0.02 \\
\hline $\mathrm{Cs}_{2} \mathrm{O}$ & 0.0002 & 0.0002 \\
\hline $\mathrm{Fe}_{2} \mathrm{O}_{3}$ & 5.51 & 6.41 \\
\hline $\mathrm{K}_{2} \mathrm{O}$ & 3.94 & 4.58 \\
\hline $\mathrm{MgO}$ & 2.03 & 2.36 \\
\hline $\mathrm{MnO}_{2}$ & 0.09 & 0.10 \\
\hline $\mathrm{Na}_{2} \mathrm{O}$ & 0.73 & 0.85 \\
\hline $\mathrm{P}_{2} \mathrm{O}_{5}$ & 0.19 & 0.22 \\
\hline $\mathrm{SiO}_{2}$ & 47.2 & 54.9 \\
\hline Sro & 0.03 & 0.03 \\
\hline $\mathrm{TiO}_{2}$ & 0.74 & 0.86 \\
\hline $\mathrm{V}_{2} \mathrm{O}_{3}$ & 0.01 & 0.01 \\
\hline $\mathrm{ZrO}_{2}$ & 0.034 & 0.039 \\
\hline $\mathrm{H}_{2} \mathrm{O}$ & 14.0 & 0.0 \\
\hline Weight $\%$ oxide & 100.0 & 100.0 \\
\hline
\end{tabular}

metal pool spreads between two or more of the electrodes. In this situation very little heating occurs, and the electrodes must be withdrawn from the metal pool to continue vitrification.

The tank, constructed of $0.32-\mathrm{cm}-(1 / 8-\mathrm{in},-)$ thick mild steel, was covered with a nominal $2.5 \mathrm{~cm}(1.0-\mathrm{in}$.) layer of concrete. The tank as it appeared before adding the outer concrete layer is shown in Figure 5. Exit piping and airlift circulators were added to the tank to more completely simulate an actual DOE underground tank. The exit piping also permitted monitoring of pressure fluctuations during processing. A $2.5-\mathrm{cm}(1-i \mathrm{n}$.$) layer$ of simulated sludge was added to the tank. with clean ORNL soil used to fill the remaining void space in the tank. 


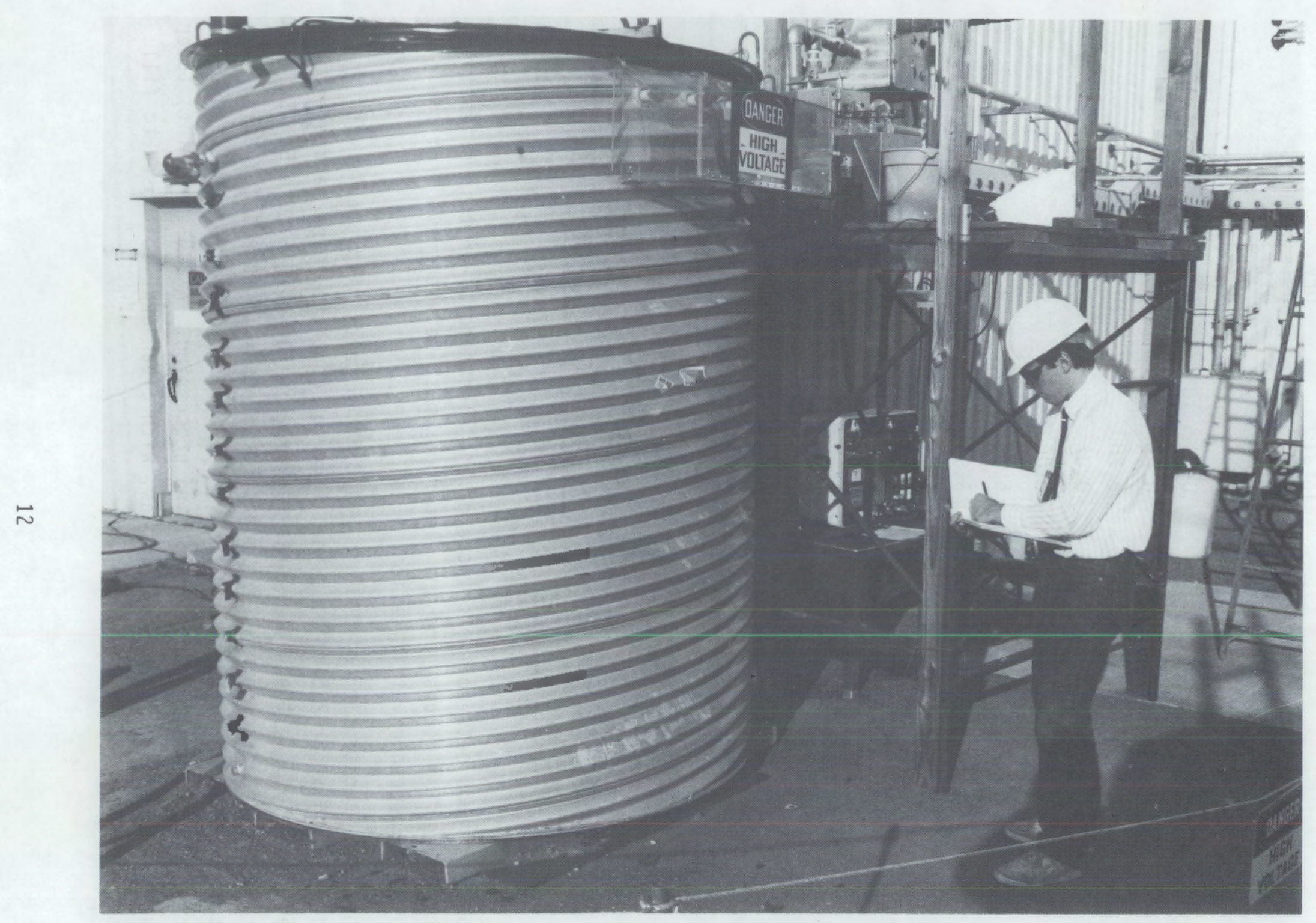

EIGURE 2. Engineering-Scale Test Containment 


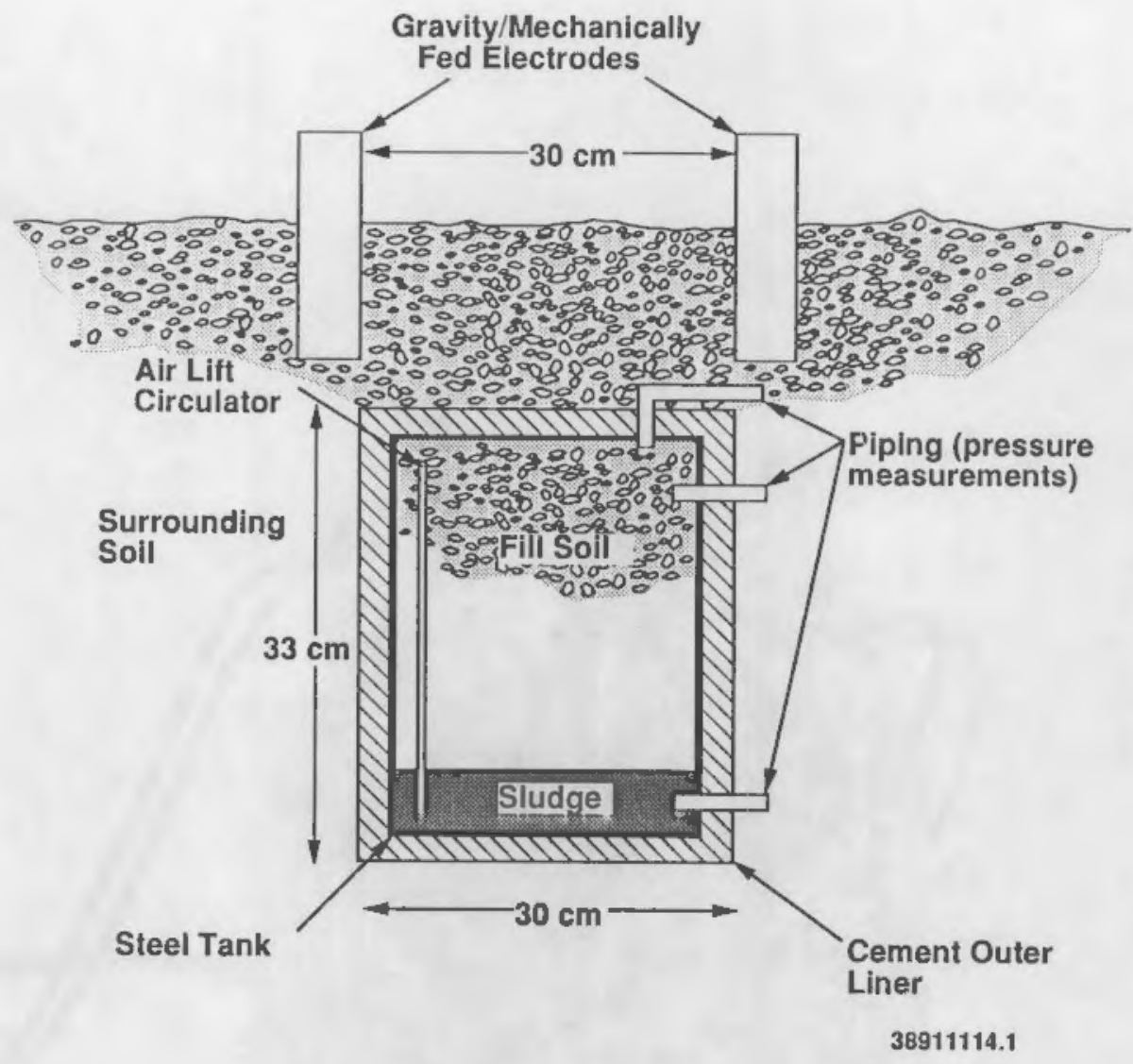

EIGURE 3. Schematic of Engineering-Scale ISV Test Configuration

Thermocouples were installed vertically in the center of the test drum and horizontally at the tank midpoint to monitor the melt shape. The upper vertical Type $K$ thermocouple was placed $5-\mathrm{cm}\left(2-i_{\text {. }}\right)$ below the soil surface and then at $5-\mathrm{cm}(2-i n$.) intervals to a depth of $104 \mathrm{~cm}$ (41 in.). A Type $\mathrm{K}$ thermocouple possesses a maximum temperature limit of $1400^{\circ} \mathrm{C}$. In addition. nine Type $k$ thermocouples were placed at the $31-\mathrm{cm}(12-i n$.) depth to monitor the horizontal growth of the melt and various isotherms in the surrounding uncontaminated soil. The isotherm information was used to determine locations for samples in the surrounding soil. These thermocouples were spaced at $5-\mathrm{cm}$ (2-in.) intervals, starting at the plane of the electrode array and moving out to the edge of the test drum.

The actual temperature of the vitrified melt was monitored using a Type $C$ thermocouple. A Type $C$ thermocouple is a more expensive junction of tungsten-5\% rhenium and tungsten-26\% rhenium in a molybdenum sheath. It is capable of reading molten glass temperatures up to $2300^{\circ} \mathrm{C}$, but because of rapid oxidation of the molybdenum sheath at high temperatures, it has a 


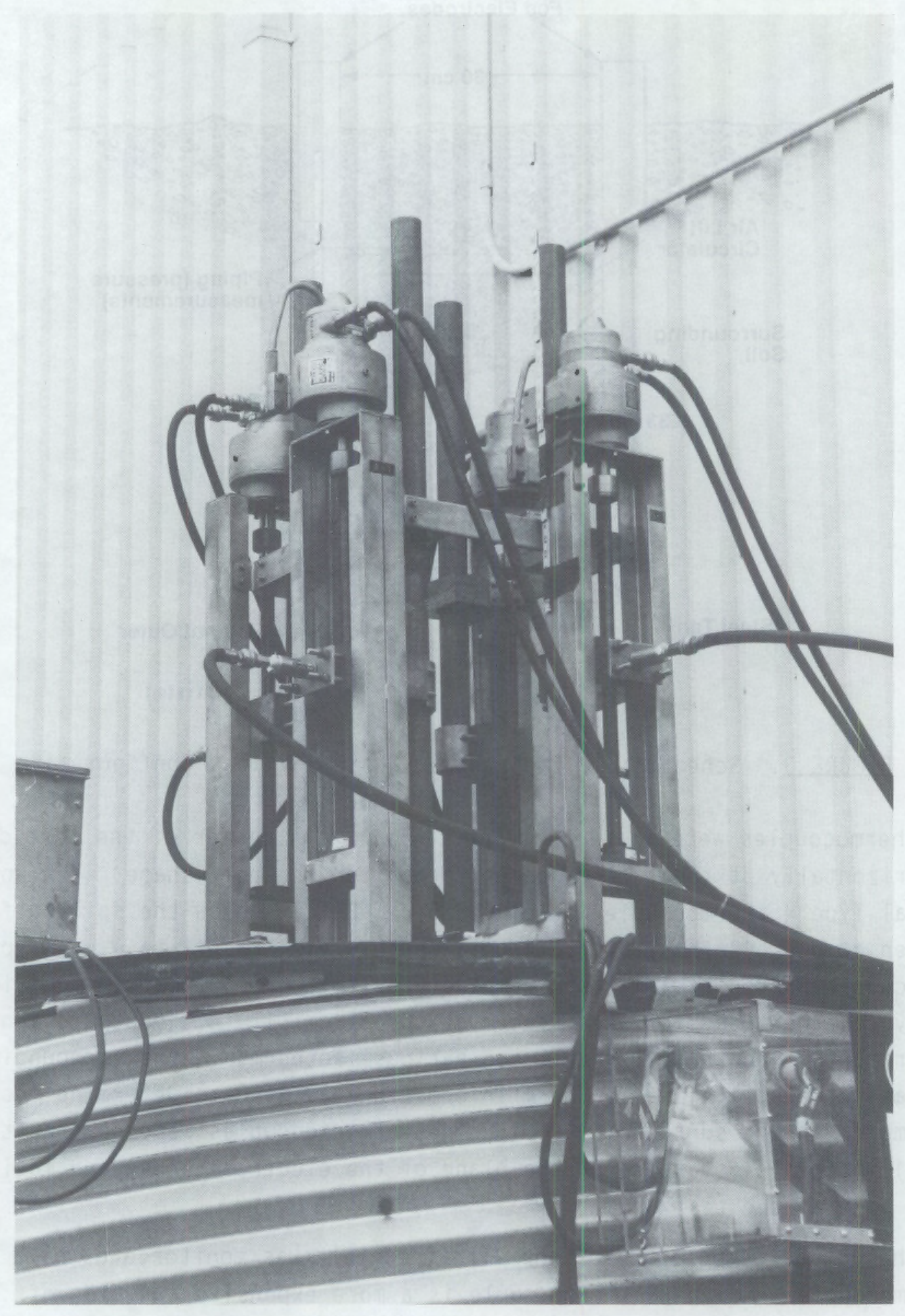

EIGURE 4. Electrode Feeding System 


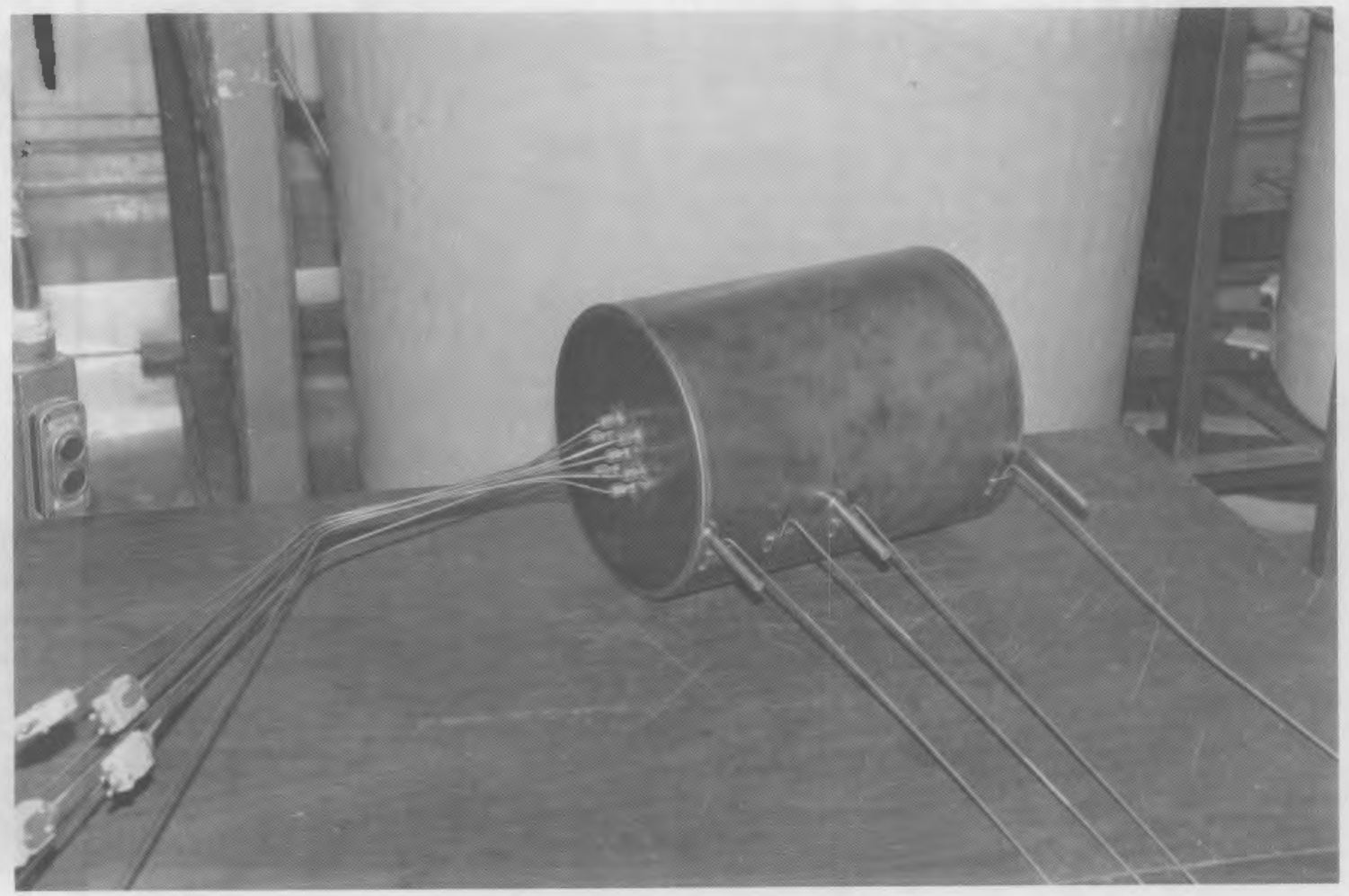

EIGURE 5. Metal Tank Prior to Addition of Concrete Coating

limited service life above $1700^{\circ} \mathrm{C}$. An alumina sheath was placed over the Type $C$ thermocouple to prevent excessive oxidation from occurring. The Type $C$ thermocouple was located in the center of the melt area, directly beneath the tank. The Type $C$ thermocouple was also used as a secondary indication to verify that the process had vitrified down past the bottom of the tank. Figure 6 shows the tank as it was being installed in the test container.

A starter path consisting of graphite flake and glass frit was laid in a square and " $X$ " pattern so that a direct conductive path was provided among the four electrodes.

The power system used in this engineering-scale test consisted of a twophase 30-kW capacity Scott-Tee transformer. The transformer contained 16 voltage taps and was wired for secondary control with each phase having a saturable reactor. The test was set to run at a target control power of $15 \mathrm{~kW}$ to more closely match power densities anticipated for the large-scale system. 


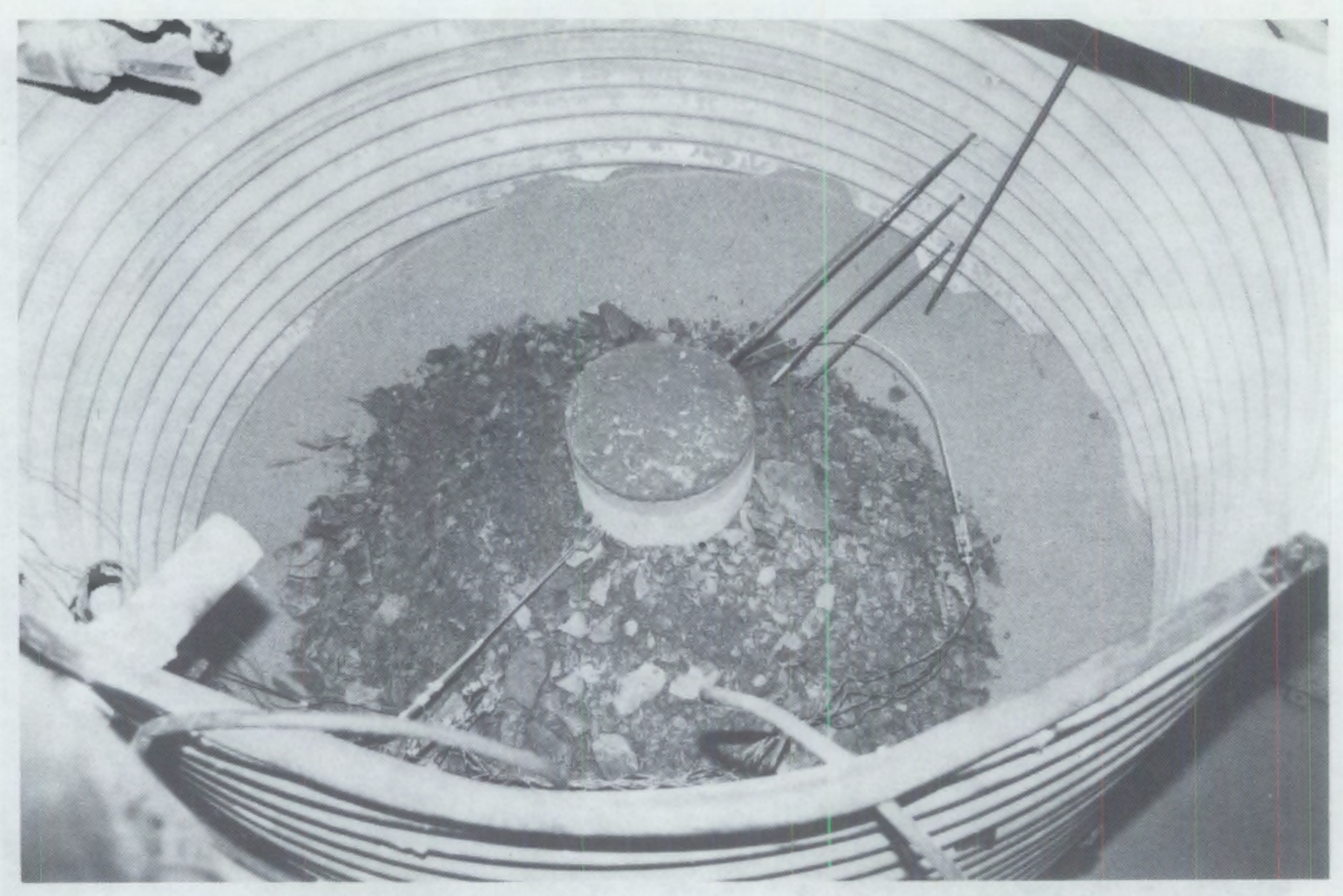

EIGURE 6. Simulated Tank in Vitrification Test Chamber

\section{DFF-GAS SYSTEM}

The off-gas sampling system was designed to collect particulates and volatile compounds present in the simulated sludge and the uncontaminated ORNL soil. The sampling train used in this test was an approved modification of EPA method 5 consisting of a heated glass fiber filter, two $500-\mathrm{mL}$ gas impingers, a silica gel bed, a vacuum pump, a flow meter, and a wet test meter (Figure 7). A portion of the total off-gas stream was isokinetically drawn through the sampling system and then piped back to the ISV system off gas. 


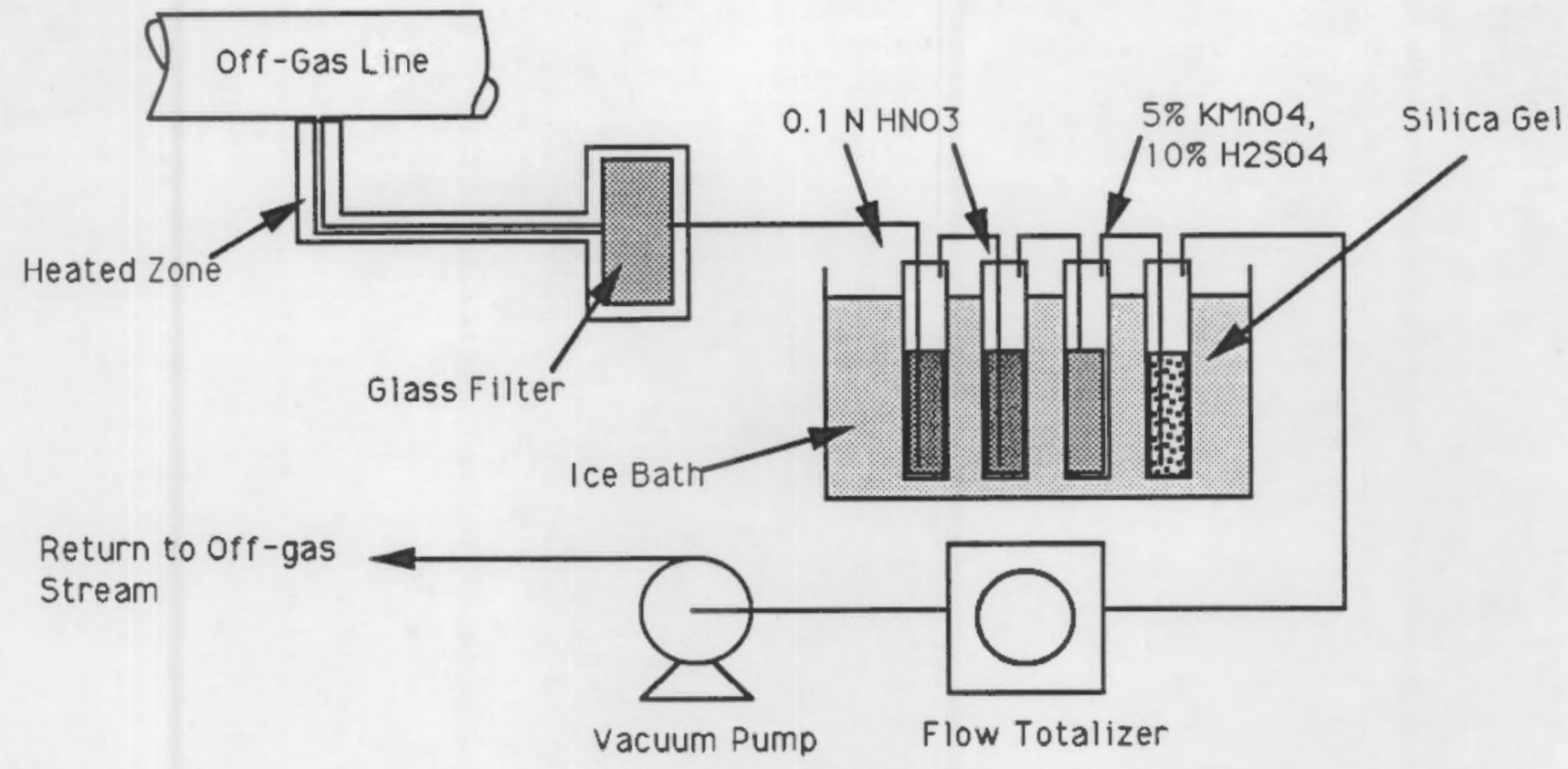

EIGURE 7. Engineering-Scale Sampling System 



\section{IEST OPERALIONS}

The UTV engineering-scale test was completed on September 14, 1989 after a run time of 23.5 hours. Because void fractions in the soil prevented a continuous starter path from developing during startup, a 5-cm (2-in.) 1ayer of sand was placed over the soil to provide a more consistent matrix for the formation of a starter path. The layer of sand allowed the test to be successfully restarted.

Voltage and current fluctuations, which are common during engineeringscale test startup when buried, fixed electrodes are used, were evident throughout the test. Early in the test, these fluctuations were attributed to occasional arcing among the graphite particles as the starter path was consumed by oxidation. Later in the test, the fluctuations appeared to be due to intermittent difficulty in feeding the electrodes downward. Operating experience has demonstrated that arcing during startup occurs more frequently in the smaller-scale tests than with the large-scale system.

After the successful startup of the test, $338 \mathrm{kWh}$ of electrical energy were consumed in the melt area over the 23.5-hour test period. As observed in previous tests, a slow decrease in the electrical resistivity between the electrodes occurred as the test proceeded. This decrease in resistivity occurs because melting of more soil provides additional charge-carrying ions. The resistivity of the melt continues to decrease until the molten glass reaches an equilibrium operating temperature. This equilibrium occurred 17 hours into the test, at a resistivity of 0.6 ohms. Figure 8 shows the total power input to the soll as a function of time. As the resistivity decreases, current to the electrodes is controlled to maintain a relatively constant power input of $15 \mathrm{~kW}$ to the melt.

The average off-gas flow rate exiting the process containment during the test was $672 \mathrm{~L} / \mathrm{min}(23.7 \mathrm{cfm})$. From this flow, a representative sample was drawn isokinetically through a stainless steel sample tube and through the offgas sampling train at $24 \mathrm{~L} / \mathrm{min}(0.86 \mathrm{cfm})$.

The vitrification process produced a block weighing $201 \mathrm{~kg}$ (442 ib). The maximum melt temperature recorded during the test was $1610^{\circ} \mathrm{C}$. Vitrification proceeded to a nominal depth of $60 \mathrm{~cm}$ (24 in.). with a maximum depth of $66 \mathrm{~cm}$ (26.0 in.) observed on one side of the block (Figure 9). The block was 


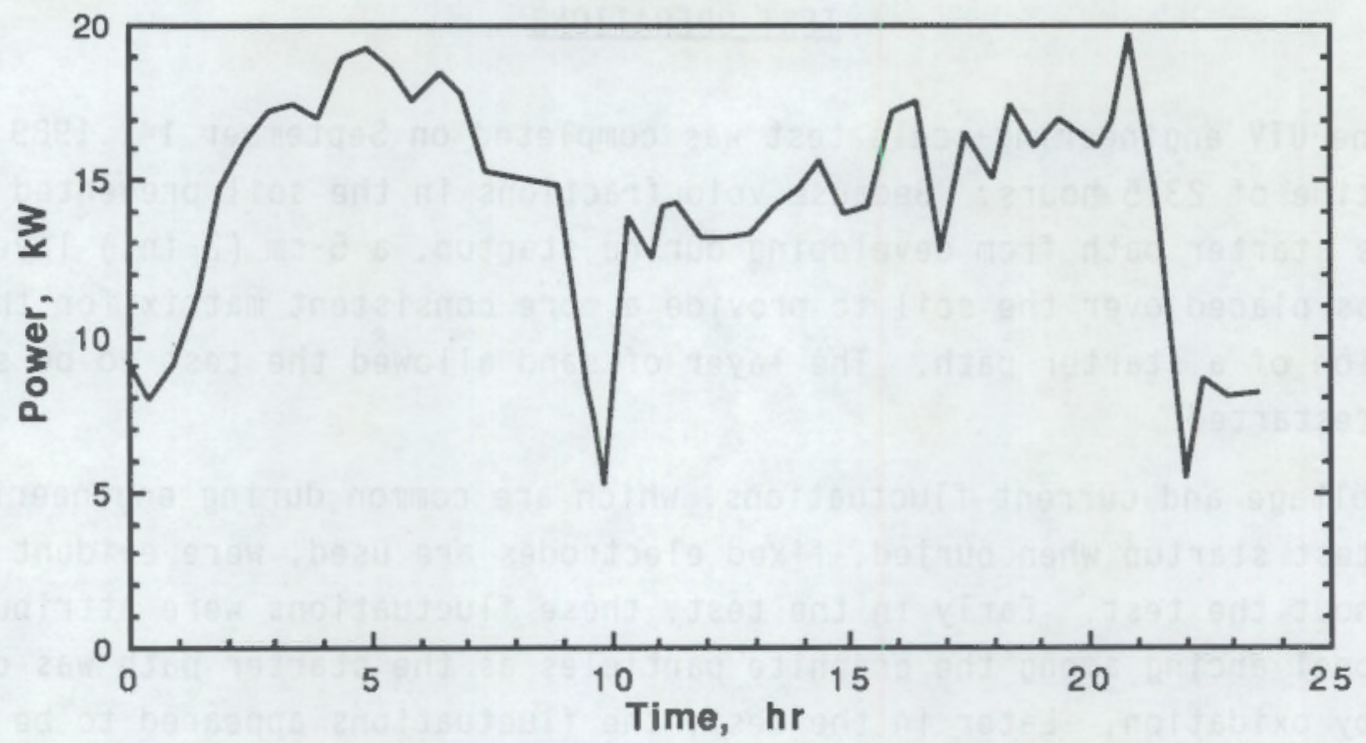

EIGURE 8. Electrical Power Input to UTV Test

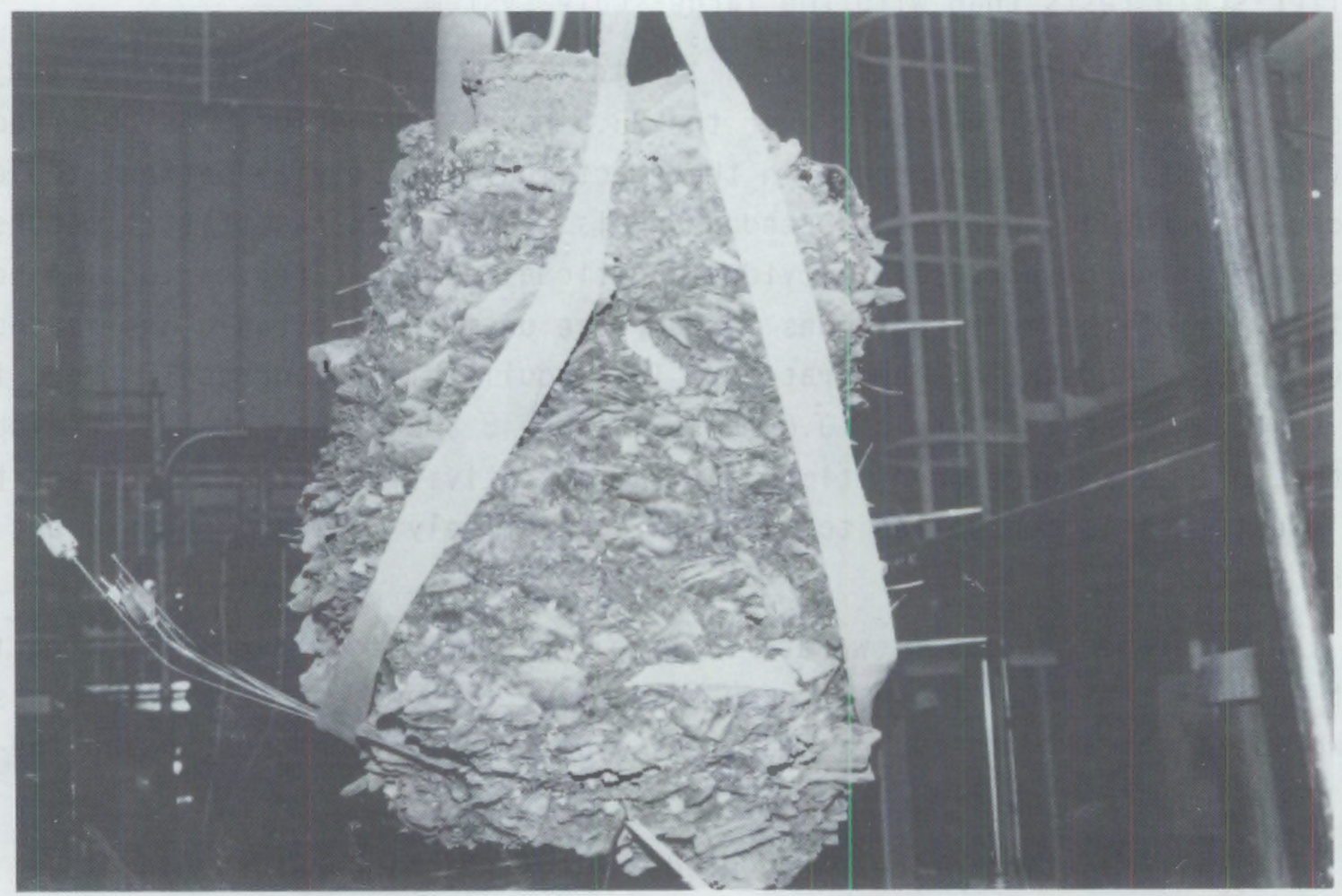

EIGURE 9. UTV Engineering-Scale Vitriffed Block 
relatively square, with approximately $40-\mathrm{cm}(16-i \mathrm{n}$.$) sides and rounded edges.$ The sides of the block were vertical (rather than the tear drop shape frequently observed) presumably due to the effects from the electrode feed system and the metal present in the vitrified zone. It appears that the metal in the tank served as a passive electrode, concentrating the power density between the electrodes and directing the melt downward instead of laterally.

No subsidence was evident at the surface of the melt, although a void space approximately $10 \mathrm{~L}(700 \mathrm{in.3})$ was found at the top of the block in between the electrodes. The void space was caused by cooling of the surface glass and the subsequent formation of a cold cap over the melt area. The high viscosity of the glass and the silicon-carbide coating on the electrodes contributed to the formation of the cold cap, which caused the glass to adhere to the electrodes and bridge across the surface instead of slumping into a subsidence. Observations made after completion of the test showed that the insulation placed over the melt area had been incorporated into the vitrified block. thus eliminating its ability to promote subsidence by preventing a cold cap from forming.

The glass and crystalline block exhibited physical characteristics similar to those produced in previous ISV tests (Figure 10). The interior of the vitrified block was relatively homogeneous, indicating that the contents of the sludge and the fill material as well as some surrounding soil were mixed during melting. Further investigation indicated that, as predicted, the metal had melted and migrated downward to just above the interface of molten glass and soil.

As predicted, electrical shorting conditions developed when the steel tank walls melted forming a semi-continuous molten metal pool between the electrodes at the bottom of the melt. Recovery from shorting conditions was accomplished by raising the electrodes $1 \mathrm{~cm}$ for about an hour then resuming the vitrification downward. Intermittent difficulty was encountered during the test in feeding the electrodes downward, resulting in the eventual binding of one electrode 6 hours into the test (Figure 11). Binding is believed to have resulted from molten soil adhering to the silicon-carbide coating used on the electrodes. The depth of the other electrodes was not ultimately affected by the adhesion of glass. It is expected that electrode binding will not 


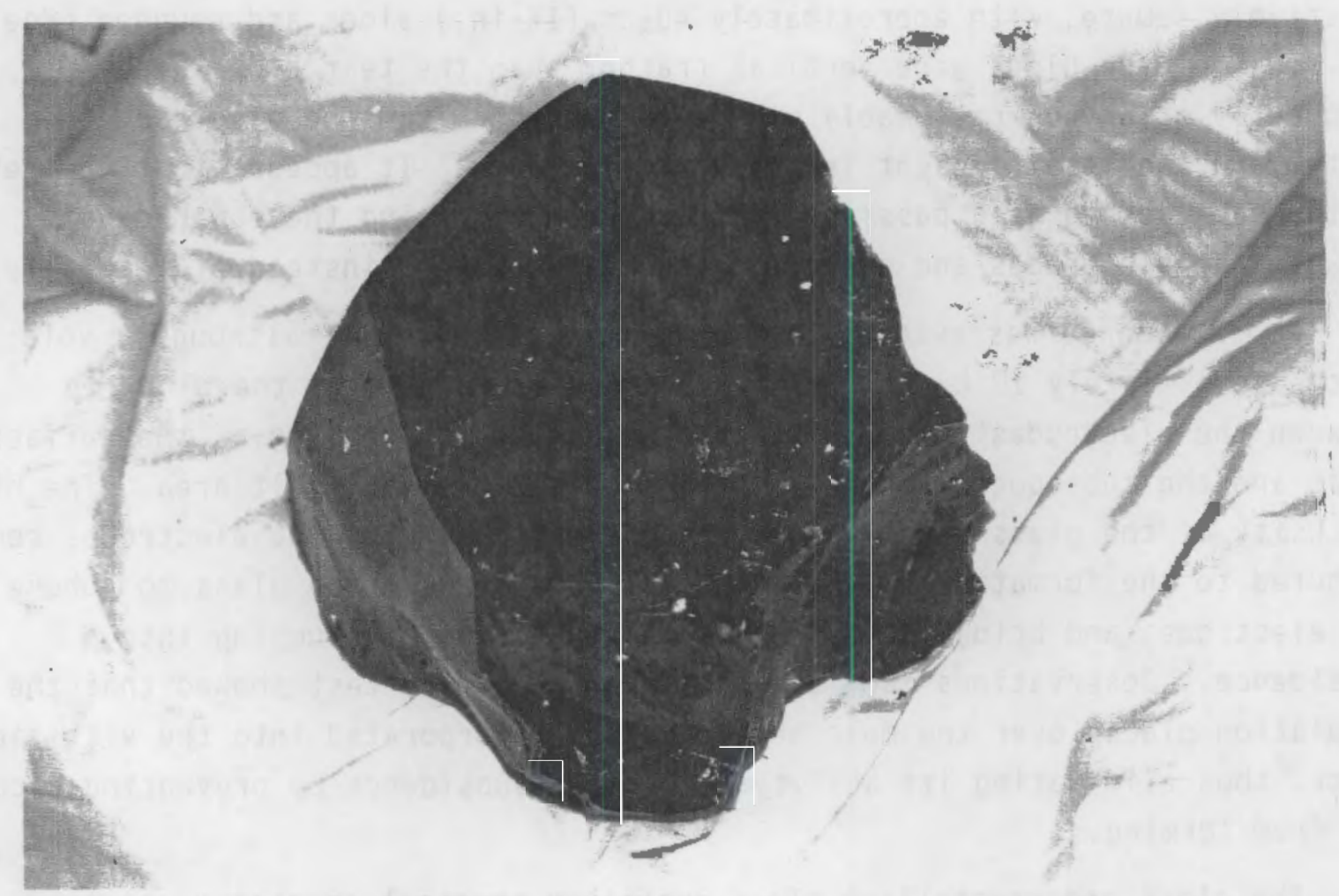

EIGURE 10. Glass Produced from Underground Tank Vitrification

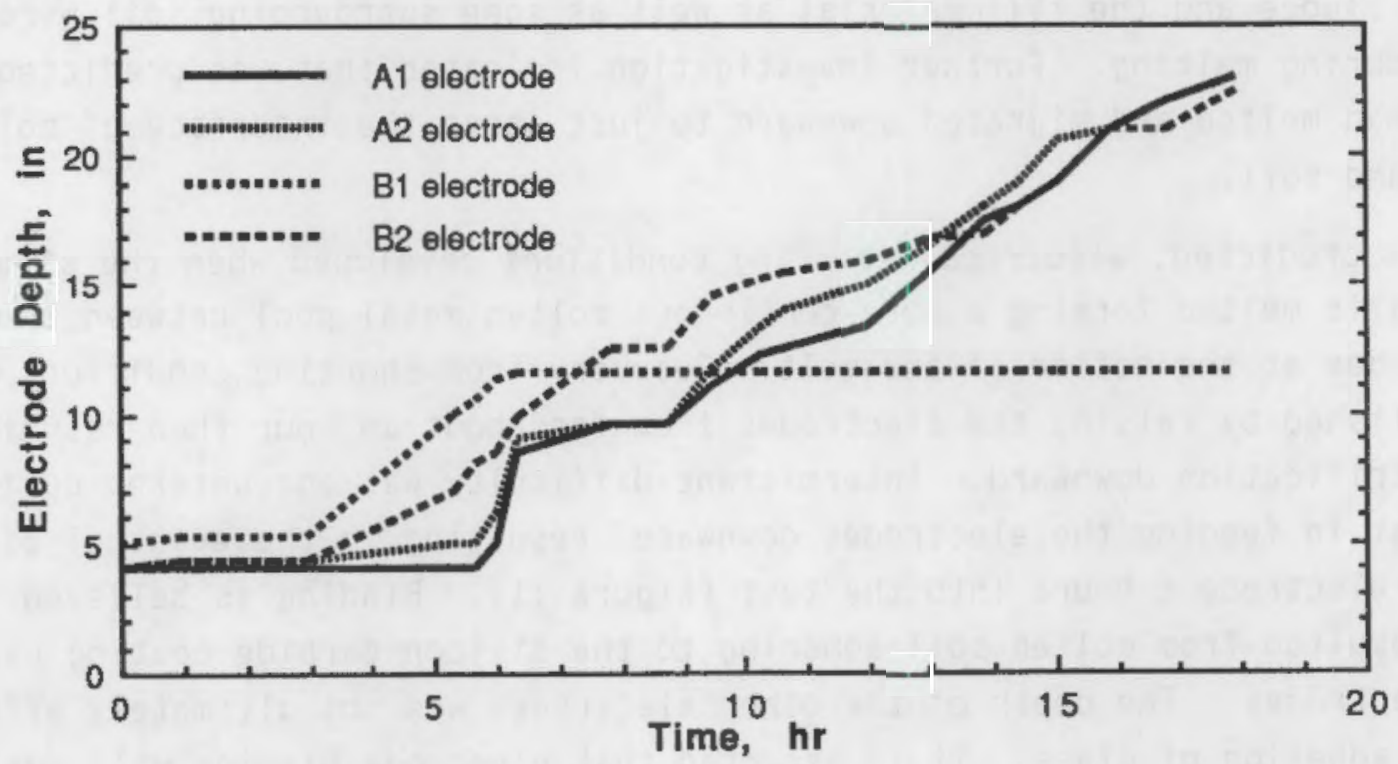

EIGURE 11. Electrode Feed Rates 
occur with the larger scale systems because of increased surface heat transfer around the electrodes for larger scale tests and the use of stronger electrode gripping and moving devices.

Throughout the test. the depth of vitrification was determined by monitoring both the depth of the gravity-fed electrodes' and the buried thermocouple temperatures. Except during startup. when the electrodes' tips were buried $10 \mathrm{~cm}$ ( $4 \mathrm{in}$.) deep, and during shorting periods when they were slightly withdrawn. the electrodes gravity fed to the bottom of the melt area. Figure 12 compares the average electrode depth with the $1200^{\circ} \mathrm{C}$ isotherm depth. Once a 15- kW power level was achieved, the electrodes fed downward at nomi. nally the same rate as the movement of the $1200^{\circ} \mathrm{C}$ isotherm. The electrode depth was consistently slightly deeper than the $1200^{\circ} \mathrm{C}$ isotherm. The greater depth for the electrodes is attributed to the preferential melting caused by higher power densities around each electrode and a fusion temperature of $1400^{\circ} \mathrm{C}$ for the ORNL soil (Carter. Bates, and Maupin 1987).

Three of the silicon-carbide coated electrodes were withdrawn from the melt following the test to observe the condition of oxidation resistant coating. No electrode oxidation was evident. Minor amounts of the coating

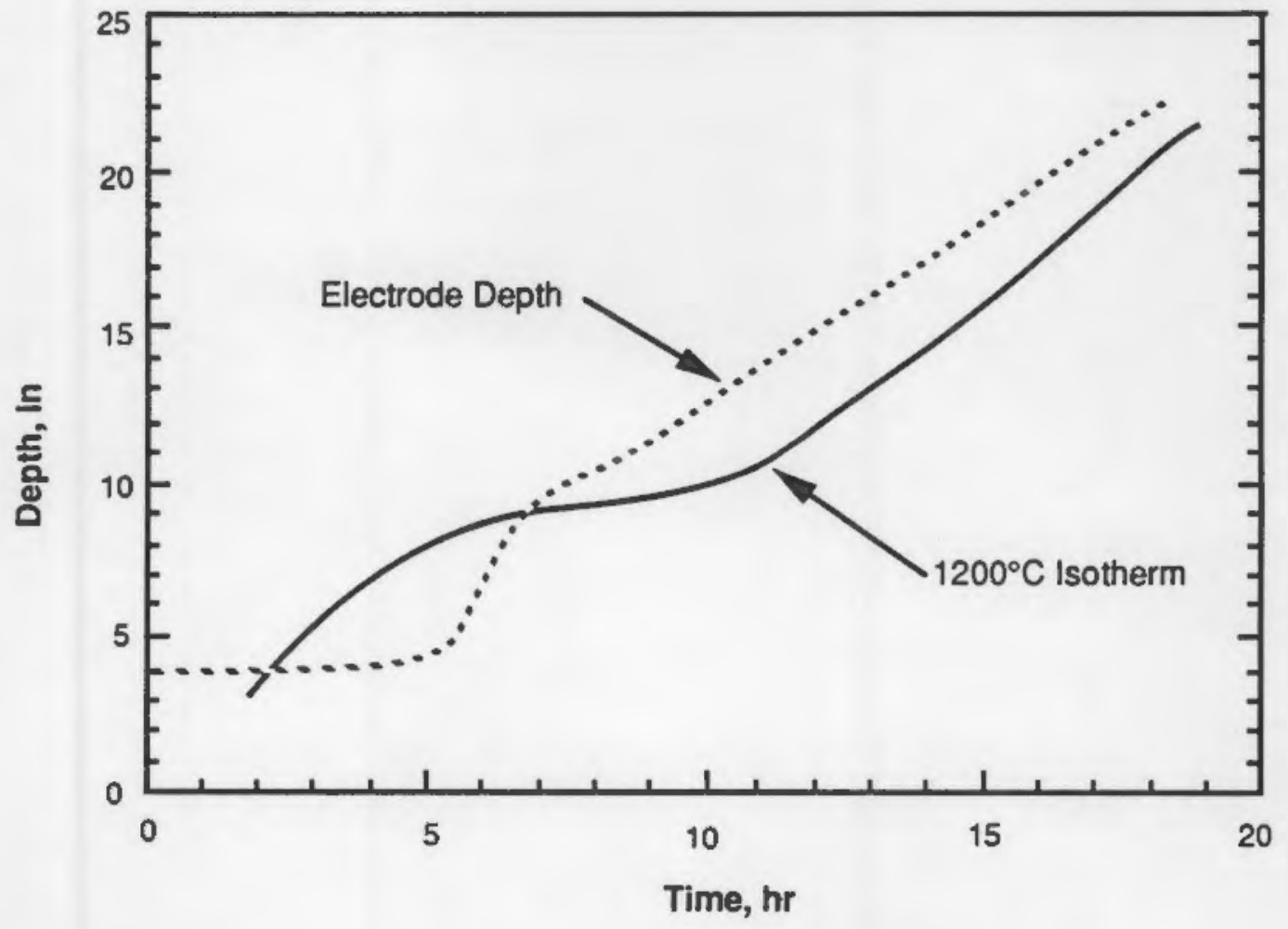

EIGURE 12. Comparison of Electrode Depth to Vitrification Depth 
flaked; however, it appeared that the coating was successful in protecting the graphite electrodes. Dissection of the block showed similar behavior for the bound electrode.

Observations from the test show that the ORNL soil was easily vitrified by the ISY process, despite the presence of $300 \mathrm{~cm}^{3}\left(18 \mathrm{in.}^{3}\right)$ of metal in the vitrification zone. Analysis of the thermocouple data indicates that a maximum tank wall temperature rise of $120^{\circ} \mathrm{C}$ up to $13 \mathrm{~cm}$ (5 in.) below the melt was present. This indicates that the metal tank wall does not provide a significant heat fin effect to the lower portion of the tank and its contents. The conductive heat transfer to the surrounding media limits any heat fin effect of the metal tank. 


\section{IESI RESULIS}

Following completion of the test, analyses were conducted on the vitrified block to determine specific material retention within the block. on the surrounding soil to determine thermal transport effects, and on the off-gas emissions to obtain release information on the volatile components added to the sludge. The analytical data indicates that an underground tank containing residual sludges can be treated using the ISV process in conjunction with an off-gas treatment system.

\section{CHARACIERIZATION OF GLASS PRODUCT AND SURROUNDING SOIL}

Of primary interest in this test was the ability of the ISV process to remediate hazardous and radionuclide-bearing sludges contained within a buried tank. Determination of contaminant concentrations contained within the vitrified product and the presence of any thermal transport effects were of impor. tance in assessing treatability by ISV. Three samples (top, middle, and bottom) of vitrified product were analyzed for the presence of the contaminants contained in the sludge. The data indicate that a fairly homogeneous block was formed. However, the volatile compounds, specifically mercury and lead. slightly decreased in concentration as melt depth increased. This is due to partial volatilizing and movement upwards through the molten area, where they eventually either evolved to the off-gas system or were concentrated and contained in the cooler upper regions of the melt. Some heavy metals $\left(\mathrm{Cr}_{2} \mathrm{O}_{3}, \mathrm{UO}_{3}\right.$, and $\left.\mathrm{Cs}_{2} \mathrm{O}\right)$ present in the sludge exhibited slightly greater concentrations as the depth of the block increased. This may be due to the sludge being initially located in the bottom of the tank and the ISV process characteristics of the engineering-scale system. It has been shown that the larger scale ISV systems provide enhanced melt mixing characteristics, thus providing a more homogeneous product (Buelt et al. 1987). 
Because of the low concentrations of some sludge components and the inherent efficiency of the ISV process, determining accurate mass balances was difficult because some materials were present at or below the detection limits of the instrumentation(a).

Surrounding soil samples were taken to determine if any species had migrated outside the vitrified zone. Sampling locations were determined by the presence of thermal gradients originating from the heat generated in the molten material. Soil samples at the $400^{\circ} \mathrm{C}$ and $100^{\circ} \mathrm{C}$ isotherms (zones where the maximum temperature reached during or after operation was $400^{\circ} \mathrm{C}$ and $100^{\circ} \mathrm{C}$ respectively) were analyzed for the components added to the sludge. No migration of heavy metal contaminants into the surrounding soil occurred. Small amounts of technetium were found in the $400^{\circ} \mathrm{C}$ soil sample: however, the concentration amounted to 10-6 percent of the total amount of Tc-99 added to the sludge. Additional samples of soil from the area next to the block, of the $400^{\circ} \mathrm{C}$ and $100^{\circ} \mathrm{C}$ isotherms, and of ambient soil have been submitted for analyses to verify the presence of technetium.

\section{QFF-GAS CHARACTERIZALION}

Off-gas sampling and analyses were conducted to quantify the contaminants evolved during processing of the simulated tank. The amount was determined by analyses of a hood smear. insulation placed over the melt area, off-gas fiber filters, impinger solutions, and a rinse solution of the off-gas sample line.

During testing, the off-gas fiber filter was changed to prevent loading of the filter. It appeared that most of the $\mathrm{Hg}$ and $\mathrm{Pb}$ volatilization occurred prior to the sludge in the tank being vitrified. This indicates that heating

(a) Some analyses of the vitrified product were complicated by interferences caused by the matrices of the samples. The normal procedure for analyzing the vitrified product and the surrounding soil involves performing a potassiumnickel fusion. which can then be analyzed by ion-coupled plasma (ICP) techniques. This technique works well for heavy metals: however, any volatile compounds present in the product are driven off during the heating process. This proved evident in analyzing for the lead, mercury, and technetium present in this test. Thus, a best available technique was used to determine the presence of the volatile compounds. A microwave chemical fusion was performed in a sealed container. which traps any compounds that volatilize. Upon cooling, the volatile species recondense into the solution and are then analyzed by ICP techniques. 
from the melt and possibly from the tank walls may have contributed to increasing the release of these volatile components early in the test operations prior to actual melting of the sludge region.

As expected, up to $50 \%$ of the volatile $\mathrm{Hg}$ and $\mathrm{Pb}$ compounds added to the sludge were released to the off-gas stream. However, particulate releases in these ranges will be effectively removed by the off-gas treatment system, which consists of wet scrubbing and filtration. Small amounts of contaminants were caught in the insulation placed over the melt area. With lead present at $2.5 \%$ of the total amount of lead added to the sludge. The sample of insulation that was analyzed was taken from the edge of the melt area since the insulation over the center of the melt was incorporated into the vitrified product. During large-scale application, insulation will be placed directly over the melt area so that all contamination caught in the insulation will be incorporated in the vitrified product or entrained in the off gas and removed by scrubbing and filtration.

Plateout of a contaminant was observed only in the case of mercury. A maximum $1.5 \%$ of the mercury in the off gas plated onto the test containment. A hood smear sample was taken directly above the melt area where previous testing (Timmerman and 0ma. 1984) has demonstrated that maximum plating occurs. Thus, the actual mercury content is expected to be far less than reported. since the calculation assumes this concentration for all surfaces available for plateout.

\section{PRODUCT EVALUATION}

Samples of the vitrified product taken from the top, middle, and bottom of the vitrified block. as well as a sample of the metal ingot, were subjected to the Extraction Procedure Toxicity (EP TOX) test. The EP Tox test measures the concentration of specific metals in leachate generated from immersing powdered vitrified product in deionized water at room temperature for 24 hours. In genera1, the EP Tox test is used to determine the regulatory requirements for final disposal of a waste form. Results of the testing are listed in Table 3 . The results obtained from the leach testing fell considerably below those limits prescribed by the EPA. 
IABLE 3. EP Toxicity Concentrations for the UTV Engineering-Scale Product

\begin{tabular}{|c|c|c|c|}
\hline Contaminant & $\begin{array}{l}\text { Glass } \\
\mathrm{md} / L\end{array}$ & $\begin{array}{l}\text { Metal } \\
\text { Ingot } \\
\text { mg } / 1 \\
\end{array}$ & $\begin{array}{l}\text { Max. Allowed } \\
\text { EP Tox Conc. } \\
\text { me/L }\end{array}$ \\
\hline Arsenic & $<0.01$ & $<0.1^{*}$ & 5.0 \\
\hline Barium & 0.006 & 0.002 & 100.0 \\
\hline Cadmium & $<0.004$ & 0.004 & 1.0 \\
\hline Chromium & $<0.02$ & $<0.02$ & 5.0 \\
\hline Lead & $<1.0$ & $<0.1$ & 5.0 \\
\hline Mercury & $<0.0001$ & $<0.0001$ & 0.2 \\
\hline Selenium & $<0.01$ & $<0.01$ & 1.9 \\
\hline silver & $<0.1$ & $<0.1$ & 5.0 \\
\hline
\end{tabular}

These results, in combination with previous testing of ORNL soil (Carter. Koegler, and Bates 1988), indicate that the vitrified product would be an excellent waste form and would provide a long-term isolation of the radioactive and hazardous components present in residual sludges contained in underground tanks.

\section{RETENTION OF RADIONUCLIDES AND HAZARDOUS CHEMICALS}

The efficiency of retaining or destroying hazardous chemicals and radionuclides by the ISV process can be expressed as a percent retention in the vitrified product. It is defined as follows:

\section{$\%$ Retention $=\left(1-M_{e} / M_{j}\right) \times 100$}

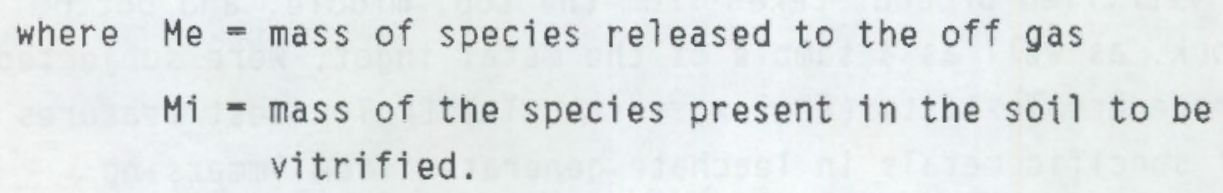

Species released during processing include those amounts present in the off-gas stream, any plateout that occurred in the head space of the system container or off-gas piping. and contamination caught in the insulation used to minimize cold cap formation.

Table 4 lists the measured and expected percent retention in the vitrified soil for the hazardous and radioactive components added to the sludge. The expected retention reflects data obtained from previous ISV testing at PNL (Buelt et al. 1987). 
IABLE 4. Contaminant Retention in the Vitrified Soil

\begin{tabular}{ccc} 
Constituent & $\begin{array}{c}\text { Measured } \\
\text { Percent } \\
\text { Retention }\end{array}$ & $\begin{array}{c}\text { Expected } \\
\text { Percent } \\
\text { Retention }\end{array}$ \\
\hline $\mathrm{Cr}$ & 99.95 & - \\
$\mathrm{Hg}$ & 46 & - \\
$\mathrm{Pb}$ & 18.7 & 97 \\
$\mathrm{U}$ & 99.994 & 99.9 \\
$\mathrm{Cs}$ & 99.992 & 99.3 \\
$\mathrm{Sr}$ & 99.98 & 99.99 \\
$\mathrm{Co}$ & 99.85 & 99 \\
$\mathrm{Tc}$ & 99.996 & -
\end{tabular}

The burial depth of the contaminants has a direct effect on retention (Buelt. Timmerman, and Westsik 1989). Data from pilot-scale and large-scale testing (Buelt et al. 1987) routinely exhibit improved retention of species in the ISV block for larger scale applications.

The effective retention of metals added to the sludge can be seen in Table 4. The small quantity of radionuclide and hazardous constituents not retained in the melt is completely removed from the gaseous effluents before being exhausted to the atmosphere. The efficiency of the off-gas system is measured by a decontamination factor (DF), which is defined as:

$$
D F=M_{j} / M_{e}
$$

where $M e=$ mass of species released to the off gas

$$
\text { Mi = mass of the species present in the soil to be }
$$
vitrified.

The DF is another way of expressing retention where $R=1-1 / D F$. The system $D F$, which includes contaminant retention in the melt and removal by the offgas system, is an overall measure of the ISV system efficiency. Typical DFs for the off-gas system, the overall system DFs and percent retention of the overall system are listed in Table 5. This test and previous testing has demonstrated effective retention of all contaminant species present in the sludge. It appears that vitrification of underground tanks will provide an effective and permanent treatment for contaminated underground tanks. 
IABLE 5. Decontamination Factors of Metals (Buelt. Timmerman and Westsik. 1989)

\begin{tabular}{|c|c|c|c|}
\hline Iype of Metal & $\begin{array}{l}\text { Off-Gas } \\
\text { Ireatment DF }\end{array}$ & $\begin{array}{l}\text { Overall } \\
\text { DF }\end{array}$ & $\begin{array}{l}\text { Overal1 } \\
\text { Percent } \\
\text { Retention }\end{array}$ \\
\hline \multicolumn{4}{|l|}{ Particulates } \\
\hline $\mathrm{Sr}, \mathrm{Pu}, \mathrm{U}, \mathrm{Cr}$ & 105 & 1010 & 99.99999999 \\
\hline \multicolumn{4}{|l|}{ Semivolatiles } \\
\hline Co, Cs, Tc & $10^{4}$ & $10^{6}$ & 99.9999 \\
\hline \multicolumn{4}{|l|}{ Volatiles } \\
\hline $\mathrm{Cd}, \mathrm{Pb}, \mathrm{Hg}$ & $10^{4}$ & 105 & 99.999 \\
\hline
\end{tabular}




\section{REFERENCES}

Autrey, J. W.. D. A. Costanoz, W. H. Griest, L. L. Kaiser, J. M. Keller, C. E. Nix, and B. A. Tomkins, 1989. Samoling and Analys is of the Inactive Waste Storage Tank Contents at ORNL. ORNL/RAP-53, Oak Ridge National Laboratory, Oak Ridge. Tennessee.

Buelt, J. L., C. L. Timmerman, K. H. Oma, V. F. FitzPatrick, and J. G. Carter. 1987. In Situ Vitrification of Iransuranic Waste: An Undated Systems Evaluation and Apolication Assessment. PNL-4800. Suppl. 1. Pacific Northwest Laboratory. Richland, Washington.

Buelt, J. L., C. L. Timmerman, and J. H. Westsik, Jr. 1989. In Situ Vitrification: Test Results for a Contaminated Sojl-Melting Process. PNL-SA15767. Suppl. 1. Pacific Northwest Laboratory. Richland, Washington.

Carter. J. G.. S. 0. Bates, and G. D. Maupin. 1987. In Situ Vitrification of Dak Ridae National Laboratory Sojl and Limestone. PNL-6174, Pacific Northwest Laboratory, Richland, Washington.

Carter, J. G., S. S. Koegler, and S. 0. Bates, 1988. Process Performance of the Pilot-Scale In Situ Vitrification of a Simulated Waste Disposal Site at the Oak Ridoe National Laboratory. PNL-6530. Pacific Northwest Laboratory. Richland. Washington.

Sewart, G. H., W. T. Farris, D. G. Huizenga, A. H. McMakin, G. P. Streile, and R. L. Treat. 1987. Long-Ierm Performance Assessment of Grouted Phosohate/Sulfate Waste from $N$ Reactor Operations. PNL-6152, Pacific Northwest Laboratory. Richland, Washington.

Timmerman. C. L., and K. H. Oma. 1984. Pilot-Scale Radioactive Test. PNL5240. Pacific Northwest Laboratory. Richland, Washington. 

DISTRIBUTION

No. of

Copies

\section{DEFSITE}

12 DOE/Office of Scientific and Technical Information

T. B. Hindman, DP-12

DOE Office of Defense Programs GTN

Washington. DC 20545

H. F. Walter, EM-343

DOE Office of Waste Operations GTN

Washington, DC 20545

5 DOE Office of Environmental Restoration and Waste Management

Forrestal Building

Washington. DC 20585

ATTN: C. R. Cooley, EM-55

T. D. Anderson, EM-442

C. Frank, EM-50

S. Prestwich, EM-52

S. P. Mathur, EM-54

J. Arthur

DOE Albuquerque Operations office

P.0. Box 5400

A1buquerque, NM 87185

E. Maestas

DOE West Valley Project

P.0. Box 191

West Valley, NY 14171

3 DOE Idaho Operations Office

785 DOE Place

Idaho Falls, ID 83402

ATTN: J. P. Hamric

H. W. Shupe
No. of

Cooies

W. T. Goldston

DOE Savannah River Operations Office

P.0. Box A

Aiken. SC 29801

M. J. Steindler, CMT-205

Argonne National Laboratory

9700 South Cass Avenue

Argonne, IL 60439

3 Battelle Memorial Institute

505 King Avenue

Columbus, OH 43201

ATTN: W. A. Carbeiner

R. A. Nathan

Technical Library

L. D. Ramspott, L209

Lawrence Livermore National Laboratory

University of California

P.0. Box 808

Livermore, CA 94550

M.A.H. Reimus

Los Alamos National Laboratory

P.0. Box 1663

Los Alamos, NM 87545

4 Oak Ridge National Laboratory

P.0. Box Y

Oak Ridge, TN 37830

ATTN : G. K. Jacobs

L. J. Mezga

T. A. Row

B. P. Spalding

2 Sandia Laboratories

P.0. Box 5800

Albuquerque, NM 87185

ATTN: R. W. Lynch

Technical Library 
No. of

Copies

12

EG\&G Idaho

P.0. Box 1625

Idaho Falls. ID 83415

ATTN: S. 0. Bates

B. L. Charboneau (5)

T. L. Clements

J. L. Landon

D. Nickelson

R. M. Schletter

N. Smith

J. R. Weidner

J. R. Berreth

Westinghouse Idaho Nuclear

Co... Inc.

P.0. $80 \times 4000$

Idaho Falls. ID 83401

5 Westinghouse Savannah River

Company

Aiken, SC 29801

ATTN: R, G. Baxter

J. Haselow

C. M. Jantzen

M. J. Plodinec

J. Steele

J. M. Pope

West Valley Nuclear

Services Co.

P.O. Box 191

West Valiey, NY 14171

4 Geosafe Corporation

Kirkland Park Place

303 Park Place. Suite 126

Kirkland. WA 98033

ATTN: V. F. FitzPatrick

C. L. Timmerman

J. G. Carter

S. L. Liikala

\section{ONSIIE}

8 DOE Richland Operations Office

E. A. Bracken, $A 6-95$

G. J. Bracken. $A 6-80$

P. K. Clark, A6-80
No. of

Copies

P. F. Dunigan. A6-95

M. J. Furman. A6-80

R. E. Gerton. $A 6-80$

R. D. Izatt. A6-95

J. J. Sutey, A5-90

10 Westinahouse Hanford Company

J. W. Cammann. H4-54

K. R. Fecht, H4-56

R. E. Lerch, B2-35

H. E. McGuire, B2-35

J. L. Scott, R2-87

J. C. Sonnichsen, H4-54

D. A. Turner, R1-10

D. D. Wodrich. R1-48

R. D. Wojtasek. B2-15

B. A. Wolfe, L5-61

49 Pacific Northwest Laboratory

C. E. Bigelow, P7-44

W. F, Bonner, P7-44

T. M. Brouns, $P 7-44$

J. L. Buelt, $P 7-44$

H. C. Burkholder, P7-41

B. E. Campoel1, P7-44 (20)

C. C. Chapman, P7-41

T. T. Claudson, K1-66

R. K. Farnsworth, P7-44

R. D. Gibby, P7-44

W. 0 . Heath. P7-44

C. H. Kindle, $P 7-44$

D. E. Knowlton, P7-40

S. S. Koegler, P7-44

W. L. Kuhn, P7.14

J. L. MCElroy, P7-46

K. A. Parnell, P7-14

M. E. Peterson. P7-44

T. D. Powell, P7-44

J. W. Shade, P8-37

C. M. Smith, P7-43

J. A. Stott lemyre. K6-78

L. E. Thompson, P7-44

Publishing Coordination

Technical Report Files (5) 